\title{
Interior Surface Modification of Bacteriophage MS2
}

Jacob M. Hooker, Ernest W. Kovacs and Matthew B. Francis*

Department of Chemistry, University of California, Berkeley, CA 94720-1460, and Material Science Division, Lawrence Berkeley National Labs, Berkeley, CA 94720-1460

\section{Supporting Information}

\section{General Procedures and Materials}

Unless otherwise noted, all chemicals were of analytical grade obtained from commercial sources and used without further purification. Analytical thin layer chromatography (TLC) was performed on EM Reagent $0.25 \mathrm{~mm}$ silica gel $60-\mathrm{F}_{254}$ glass plates with visualization by ultraviolet (UV) irradiation at $254 \mathrm{~nm}$ and/or staining with iodine, ceric ammonium molybdate (CAM), potassium permanganate, or ninhydrin. Purifications by flash chromatography were performed using EM silica gel 60 (230-400 mesh). The silica gel:compound ratio was approximately 100-150. The eluting system for each purification was determined by TLC analysis. Chromatography solvents were used without distillation unless otherwise noted. Dichloromethane was distilled under a nitrogen atmosphere from calcium hydride. All reactions were carried out under a nitrogen atmosphere unless otherwise noted. Water $\left(\mathrm{ddH}_{2} \mathrm{O}\right)$ used in biological procedures or as reaction solvents was deionized using a NANOpure ${ }^{\mathrm{TM}}$ purification system (Barnstead, USA). All organic solvents were removed under reduced pressure using a rotary evaporator. Reported atomic percentages are within error limits of $\pm 0.4 \%$.

\section{Instrumentation and Sample Analysis Preparations}

Infrared spectra were obtained as potassium bromide pellets on a Genesis II FTIR ${ }^{\text {TM }}$ (ATI Mattson, USA). Uncorrected melting points were determined in glass capillary tubes using a Mel-Temp $3.0^{\circledR}$ apparatus (Laboratory Devices, Inc., USA). UV-Vis spectroscopic measurements were conducted on a Tidas-II benchtop spectrophotometer ( $\mathrm{J} \& \mathrm{M}$, Germany). Centrifugations were conducted with the following: 1) Allegra 64R Tabletop Centrifuge (Beckman Coulter, Inc., USA); 2) Sorvall RC5C refrigerated high-speed centrifuge (Sorvall, USA); or 3) Microfuge ${ }^{\circledR} 18$ centrifuge (Beckman Coulter, Inc., USA). 
General desalting and removal of other small molecules of biological samples were achieved using BioSpin ${ }^{\circledR}$ G-25 centrifuge columns (Amersham Biosciences, USA), $\mu$ C18 ZipTip ${ }^{\circledR}$ columns (Millipore, USA), NAP-10 ${ }^{\mathrm{TM}}$ gel filtration columns (Amersham Biosciences, USA). Prior to analysis of all MS2 capsid samples, reaction solutions were passed through $50 \mathrm{mg}$ of Sephacryl ${ }^{\mathrm{TM}}$ S-300 High Resolution resin (Amersham Biosciences, USA) pre-equilibrated in the desired elution buffer and packed in BioSpin ${ }^{\circledR}$ columns using centrifugation (750 rpm, 2 min, $4{ }^{\circ} \mathrm{C}$ ). Only assembled MS2 particles elute using this method.

NMR. ${ }^{1} \mathrm{H}$ and ${ }^{13} \mathrm{C}$ spectra were measured with a Bruker AM-400 (400 MHz) spectrometer. Chemical shifts are reported as $\delta$ in units of parts per million (ppm) relative to chloroform- $d(\delta$ $7.26, \mathrm{~s})$, dimethyl sulfoxide- $d_{6}(\delta 2.50$, pentet), or methanol ( $\delta 3.31$, septet). Multiplicities are reported as follows: $\mathrm{s}$ (singlet), $\mathrm{d}$ (doublet), $\mathrm{t}$ (triplet), $\mathrm{q}$ (quartet), $\mathrm{dd}$ (doublet of doublets), $\mathrm{m}$ (multiplet), br (broadened), or app (apparent). Coupling constants are reported as a $J$ value in Hertz (Hz). The number of protons (n) for a given resonance is indicated $\mathrm{nH}$, and is based on spectral integration values. ${ }^{13} \mathrm{C}$ NMR spectra are reported as $\delta$ in units of parts per million (ppm) relative to chloroform- $d(\delta 77.23, t)$, dimethyl sulfoxide- $d_{6}\left(\delta 39.50\right.$, septet), or methanol- $d_{4}(\delta$ 49.17, septet).

Transmission Electron Microscopy. Transmission Electron Microscopy (TEM) images were obtained at the UC-Berkeley Electron Microscope Lab using a FEI Tecnai 12 transmission electron microscope with $100 \mathrm{kV}$ accelerating voltage. Protein samples were prepared for TEM analysis by submerging carbon-coated copper grids into solutions of analyte at approximately 0.1 $\mathrm{mg} / \mathrm{mL}$ for 4-5 min and then rinsing with $\mathrm{ddH}_{2} \mathrm{O}$. The grids were then exposed to a $2 \%$ solution of uranyl acetate (UA) for $1 \mathrm{~min}$ as a negative stain. After excess stain was removed by blotting, the grid was rinsed again with $\mathrm{ddH}_{2} \mathrm{O}$ and dried in vacuo until analysis.

Mass Spectrometry (MS). Fast Atom Bombardment (FAB) and Electron Impact (EI) mass spectra were obtained at the UC Berkeley Mass Spectrometry Facility. Matrix Assisted Laser Desorption-Ionization Time of Flight (MALDI-TOF) mass spectra were obtained on a VoyagerDE from PerSeptive Biosystems. High resolution MALDI-TOF spectra of MS2 digest peptides were obtained on a Voyager-DE PRO from Applied Biosystems using previously identified unmodified digest fragments as internal standards. MALDI matrices were prepared daily as saturated solutions (generally $10 \mathrm{mg} / \mathrm{mL}$ ). For protein and peptide analysis, sinapinic acid, $\alpha$ cyano-4-hydroxycinnamic acid (CHCA), or 2,4,6-trihydroxyacetophenone (THAP) in 3:2 
$\mathrm{MeCN}: \mathrm{ddH}_{2} \mathrm{O}$ (with $0.1 \%$ TFA) in were used. In all cases, the spot overlay technique was employed for crystallization. ${ }^{1}$ Intact MS2 capsids were disassembled on the column using reversed-phase HPLC prior to MALDI-MS analysis.

High Performance Liquid Chromatography. HPLC was performed on an Agilent 1100 Series HPLC System (Agilent Technologies, USA). Protein chromatography was achieved on reversed-phase (C3, C8, or $\mathrm{C} 18300 \AA$ pore size) columns with an $\mathrm{MeCN}: \mathrm{H}_{2} \mathrm{O}$ gradient mobile phase containing either $0.1 \%$ trifluoroacetic acid or $0.1 \%$ formic acid. Size exclusion chromatography was accomplished on an Agilent Zorbax ${ }^{\circledR}$ GF-250 with isocratic $(0.5 \mathrm{~mL} / \mathrm{min})$ flow using an aqueous mobile phase $\left(100 \mathrm{mM} \mathrm{Na}_{2} \mathrm{HPO}_{4}\right.$ with $\left.0.005 \% \mathrm{NaN}_{3}, \mathrm{pH} 7.2\right)$. Sample analysis for all HPLC experiments was acheived with an inline diode array detector (DAD) and an inline fluorescence detector (FLD).

Fast Performance Liquid Chromatography. Size exclusion chromatography (SEC) was performed on a BioRad ${ }^{\circledR}$ BioLogic $^{\mathrm{TM}}$ DuoFlow FPLC System equipped with a HiPrep ${ }^{\mathrm{TM}}$ 16/60 Sephacryl ${ }^{\mathrm{TM}}$ S-200 High Resolution Column (Amersham Biosciences, USA) using an aqueous buffer as the mobile phase.

GEL Analyses. For protein analysis, sodium dodecyl sulfate-polyacrylamide gel electrophoresis (SDS-PAGE) was accomplished on a Mini-Protean apparatus from Bio-Rad (Hercules, CA), following the general protocol of Laemmli. ${ }^{2}$ All protein electrophoresis samples were heated in the presence of 1,4-dithiothreitol (DTT) to ensure reduction of any disulfide bonds unless reduction was not desired. Commercially available markers (Bio-Rad) were applied to at least one lane of each gel for calculation of apparent molecular masses. Visualization of protein bands was accomplished by staining with Coomassie ${ }^{\circledR}$ Brilliant Blue R250 or Silver Stain Solution (Bio-Rad).

\section{Experimental}

Bacteriophage MS2. Routine propagation of MS2 was carried out in a one-liter batch process using a modified procedure of Strauss and Sinsheimer. ${ }^{3}$ The growth medium for the host bacteria, E. coli, was prepared by the addition of $10 \mathrm{~g}$ TryptoPeptone, $5 \mathrm{~g}$ Bacto ${ }^{\mathrm{TM}}$ Yeast Extract, and $8 \mathrm{~g} \mathrm{NaCl}$ to 1 liter of $\mathrm{ddH}_{2} \mathrm{O}$. After autoclave sterilization of the resulting broth, $10 \mathrm{~mL}$ of sterile $10 \%$ glucose solution, $2 \mathrm{~mL}$ of sterile $1 \mathrm{M} \mathrm{CaCl}_{2}$ solution, and $1 \mathrm{~mL}$ of a sterile $10 \mathrm{mg} / \mathrm{mL}$ thiamine hydrochloride solution were added. 
Culture media were infected with revived $\mathrm{Hfr}^{+}$E. coli that had been grown from a single colony originally isolated from a freeze-dried pellet (American Type Culture Collection, ATCC, No. 15669; Rockville, MD). The infected culture was incubated at $37{ }^{\circ} \mathrm{C}$ under aerobic conditions until the optical density (OD) of 0.2 at $600 \mathrm{~nm}$ was reached, signifying exponential growth of the host bacteria. Inoculation of the bacteria was accomplished by the addition of a small aliquot of MS2 suspension stored at $4{ }^{\circ} \mathrm{C}$ that had previously been propagated from purchased stock (ATCC No.15597-B1) by a similar procedure. Propagation of the virus was carried out at $37{ }^{\circ} \mathrm{C}$ for at least $4 \mathrm{~h}$, but typically overnight to ensure complete lysis of the bacterial culture.

Isolation of the MS2 phage was performed by separation of lysed bacterial debris by centrifugation at $4500 \mathrm{rcf}$ for $30 \mathrm{~min}$ at $4{ }^{\circ} \mathrm{C}$ followed by selective precipitation by the addition of $10 \%(\mathrm{w} / \mathrm{v})$ poly(ethylene glycol) -6000 and $\mathrm{NaCl}$ to a final concentration of $0.5 \mathrm{M}$. The precipitated MS2 was then separated from the supernatant by centrifugation at 13,000 $\mathrm{rcf}$ for $1 \mathrm{~h}$ at $4{ }^{\circ} \mathrm{C}$. The resulting pellet was resuspended in $50 \mathrm{ml}$ of aqueous buffer $\left(0.5 \mathrm{M} \mathrm{Na}_{2} \mathrm{HPO}_{4}, 0.1\right.$ $\mathrm{M} \mathrm{NaCl}, \mathrm{pH}$ 7.2) and passed through a $0.22 \mu \mathrm{m}$ sterile filter (Millipore Corp., USA) under vacuum to afford MS2 phage as the only protein in solution, as determined by SDS-PAGE. Further purification of MS2 by FPLC (as described above) was performed to remove residual polymer from the precipitation step.

Empty MS2 Capsids (1). To a solution of MS2 virions was added 10\% (w/v) poly(ethylene glycol)- 6000 and $\mathrm{NaCl}$ to a final concentration of $0.5 \mathrm{M}$ to precipitate the protein capsids. The precipitate was separated via centrifugation and then dissolved in aqueous buffer $(100 \mathrm{mM}$ $\mathrm{Na}_{2} \mathrm{HPO}_{4}, 100 \mathrm{mM} \mathrm{NaCl}, \mathrm{pH} 11.8$ ). After $2.5 \mathrm{~h}$ at $\mathrm{rt}$, the protein was precipitated as outlined above and redissolved. The precipitate mixture was centrifuged at $10,000 \mathrm{rcf}$ for $30 \mathrm{~min}$ at $4{ }^{\circ} \mathrm{C}$ and the pellet was redissolved in a minimal volume of aqueous buffer $\left(100 \mathrm{mM} \mathrm{Na} 2 \mathrm{HPO}_{4}, 100\right.$ $\mathrm{mM} \mathrm{NaCl}, \mathrm{pH} 11.8$ ). After incubation at $\mathrm{rt}$ for $1.5 \mathrm{~h}$, the MS2 solution was passed through a gel filtration column via FPLC (as outlined above). The overall process afforded empty capsids in $80-90 \%$ yield of the initial phage.

Empty MS2 pH Stability Experiment. To $10 \mu \mathrm{L}$ aliquots of an aqueous solution of 1 (1.0 $\mathrm{mg} / \mathrm{mL}, 10 \mathrm{mM} \mathrm{Na}_{2} \mathrm{HPO}_{4}, \mathrm{pH} \mathrm{7.0)}$ was added $90 \mu \mathrm{L}$ of the appropriate $\mathrm{pH}$ buffer solution (150 $\mathrm{mM} \mathrm{Na}_{2} \mathrm{HPO}_{4}, \mathrm{pH} \mathrm{3-10)}$. Samples were incubated at $\mathrm{rt}$ for $12 \mathrm{~h}$ at which time the quantity of assembled capsid in solution was measured using HPLC-SEC (as outlined above) in triplicate. 
Absorbance peak areas $(\lambda=280 \mathrm{~nm})$ were averaged and are reported (as \%) relative to the same quantity of 1 incubated at $4{ }^{\circ} \mathrm{C}\left(100 \mathrm{mM} \mathrm{Na}_{2} \mathrm{HPO}_{4}, 100 \mathrm{mM} \mathrm{NaCl} \mathrm{pH} 7.2\right)$ and analyzed in the same manner that showed no loss of assembled protein over $12 \mathrm{~h}$. FLD analysis $\left(\lambda_{\mathrm{ex}}=250 \mathrm{~nm}\right.$, $\lambda_{\mathrm{em}}=330 \mathrm{~nm}$ ) provided further verification of assembled protein recovery.

Empty MS2 Capsid Azo-Conjugate (3). a) Formation of Diazonium Salt (2): To a $10 \mu \mathrm{L}$ solution of $p$-nitroaniline $(20.0 \mathrm{mg} / \mathrm{mL}, 1.45 \mu \mathrm{mol})$ was added $5 \mu \mathrm{L}$ of an aqueous solution of $p$ toluene sulfonic acid monohydrate $(160 \mathrm{mg} / \mathrm{mL}, 4.2 \mu \mathrm{mol})$ at $4{ }^{\circ} \mathrm{C}$. The resulting solution was vortexed for $1 \mathrm{~min}$ and treated with $5 \mu \mathrm{L}$ of an aqueous solution of sodium nitrite $(32 \mathrm{mg} / \mathrm{mL}$, $2.3 \mu \mathrm{mol})$. The solution was briefly vortexed and diazotization was carried out at $4{ }^{\circ} \mathrm{C}$ for $1 \mathrm{~h}$. b) Diazonium Coupling Reaction: To a $1.0 \mathrm{~mL}$ aqueous buffered solution of $1(1.2 \mathrm{mg} / \mathrm{mL}, 87$ nmol of Y85, pH $9.0150 \mathrm{mM} \mathrm{NaHPO}$ ) was added $6.0 \mu \mathrm{L}$ of $2(435 \mathrm{nmol})$. The resulting solution was vortexed briefly. Diazonium coupling was carried out at $4{ }^{\circ} \mathrm{C}$ for $15 \mathrm{~min}$. The reaction solution was passed through a gel filtration column (NAP-10) pre-equilibrated with 5 column volumes of elution buffer $\left(100 \mathrm{mM} \mathrm{Na}_{2} \mathrm{HPO}_{4}, \mathrm{pH} 7.2\right)$ and eluted in $1.5 \mathrm{~mL}$.
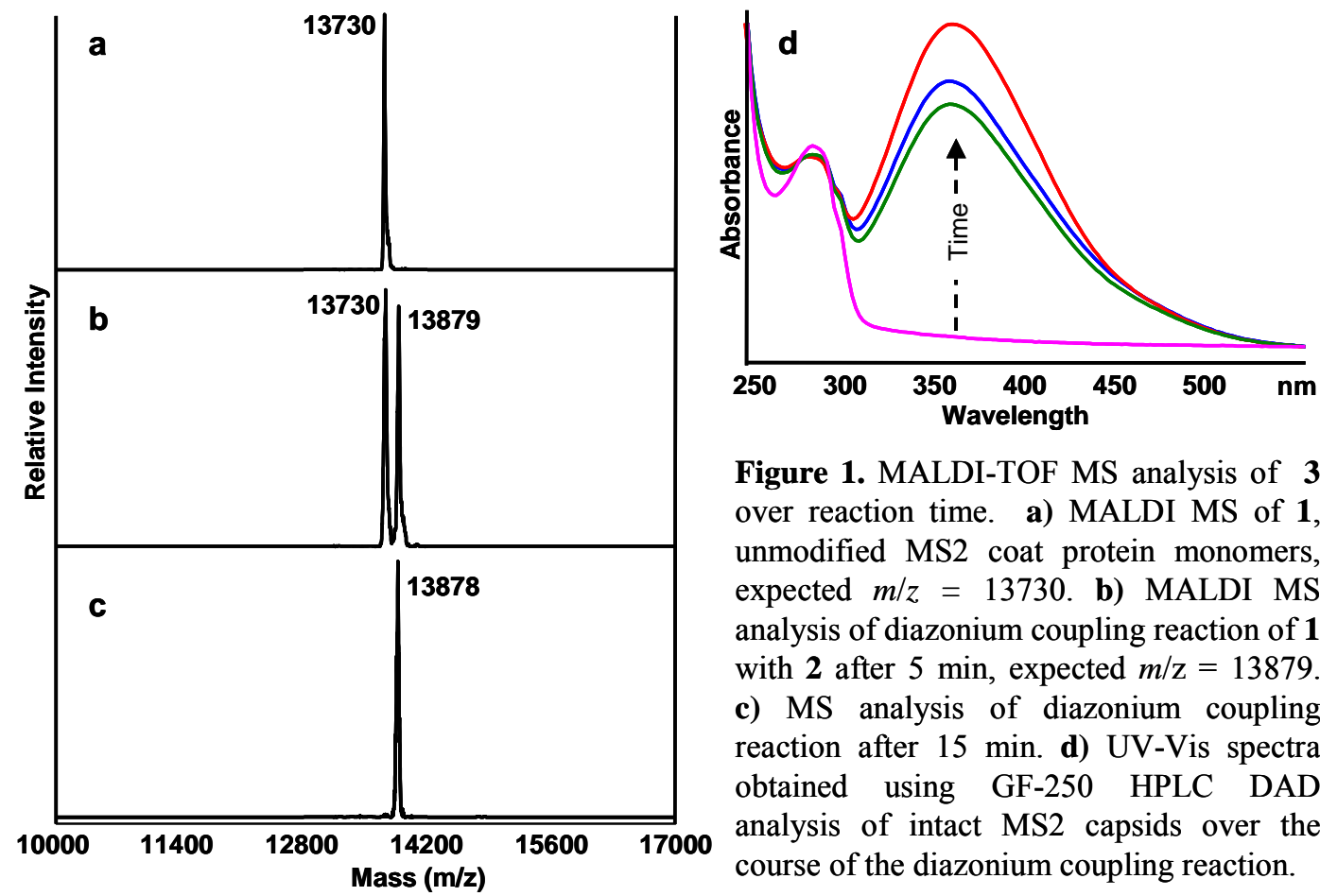

Figure 1. MALDI-TOF MS analysis of 3 over reaction time. a) MALDI MS of $\mathbf{1}$, unmodified MS2 coat protein monomers, expected $m / z=13730$. b) MALDI MS analysis of diazonium coupling reaction of 1 with 2 after $5 \mathrm{~min}$, expected $\mathrm{m} / \mathrm{z}=13879$. c) MS analysis of diazonium coupling reaction after $15 \mathrm{~min}$. d) UV-Vis spectra obtained using GF-250 HPLC DAD analysis of intact MS2 capsids over the course of the diazonium coupling reaction.

Empty MS2 Capsid o-amino-Y85 (4). To a $1.0 \mathrm{~mL}$ solution of 3 was added solid $\mathrm{Na}_{2} \mathrm{~S}_{2} \mathrm{O}_{4}$ (20 mg, $85 \%$ tech. grade). The solution was briefly vortexed and incubated at rt. After $2 \mathrm{~h}$, the 
reaction solution was passed through a gel filtration column (NAP-10) pre-equilibrated with 5 column volumes of elution buffer $\left(100 \mathrm{mM} \mathrm{NaHPO}_{4}, \mathrm{pH} 6.5\right)$ and eluted in $1.5 \mathrm{~mL}$.
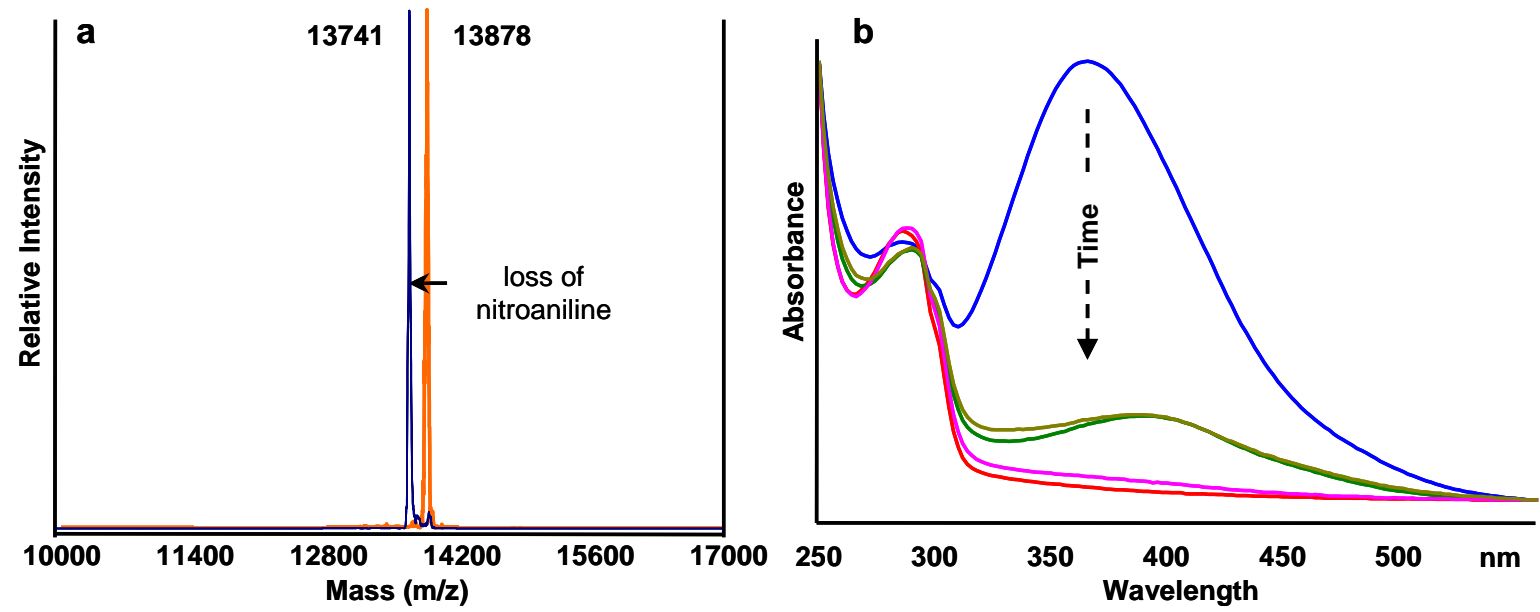

Figure 2. Characterization of Empty MS2 Capsid o-amino-Y85 (4). a) MALDI-TOF MS of 3 (orange) superimposed on MALDI-TOF MS of 4, expected $\mathrm{m} / \mathrm{z}=13745$. b) UV-Vis spectra obtained using GF-250 HPLC DAD analysis of intact MS2 capsids over the course of the azo reduction. Total loss of the chromophore occurs after $1.5 \mathrm{~h}$.

$N$-(4-aminophenyl)acrylamide (6). At $\mathrm{rt}$ under a $\mathrm{N}_{2}$ atmosphere, 1,4-phenylene diamine (1.00 g, $9.24 \mathrm{mmol}$ ) was dissolved in $100 \mathrm{~mL}$ of dry $\mathrm{CH}_{2} \mathrm{Cl}_{2}$. The resulting solution was cooled to $0{ }^{\circ} \mathrm{C}$ and treated with distilled acryloyl chloride $(0.3 \mathrm{~mL}, 4.62 \mathrm{mmol})$ (distilled on a short path distillation apparatus under $\mathrm{N}_{2}$ ). After 15 min of vigorous stirring, the reaction mixture was filtered to remove a white precipitate. The removal of the filtrate solvent under reduced pressure gave a yellow liquid which was purified by silica gel chromatography (4:1 EtOAc/Hexanes). Subsequent recrystallization from EtOAc/Hexanes afforded the desired product (425 mg, 57\%) as pale yellow solid, $\mathrm{mp} 148.6-149.8{ }^{\circ} \mathrm{C}$. IR (KBr): 3446, 3347, 3242, 3060, 1932, 1874, 1648, 1618, 1510, 1434, 1406, $1329 \mathrm{~cm}^{-1}$. ${ }^{1} \mathrm{H}-\mathrm{NMR}$ (400 MHz, DMSO-d $\left.{ }_{6}\right): \delta 9.73(\mathrm{~s}, 1 \mathrm{H}), 7.31(\mathrm{~m}$ $\left.\left(\mathrm{AA}^{\prime} \mathrm{XX}^{\prime}\right), 2 \mathrm{H}, J=8.8,2.8,2.0\right), 6.51$ (m $\left.\left(\mathrm{AA}^{\prime} \mathrm{XX}\right), 2 \mathrm{H}, J=8.8,2.8,2.0\right), 6.37$ (dd, 1H, $J=17.2$, 10.0), $6.16(\mathrm{dd}, 1 \mathrm{H}, J=17.2,2.0), 5.65(\mathrm{dd}, 1 \mathrm{H}, J=10.0,2.0), 4.91(\mathrm{~s}, 2 \mathrm{H}) .{ }^{13} \mathrm{C}-\mathrm{NMR}(100$ MHz, DMSO- $\left.d_{6}\right): \delta 162.2,145.0,132.2,128.8,125.4,120.9,113.8$. HRMS (EI+) calcd for $\mathrm{C}_{9} \mathrm{H}_{10} \mathrm{~N}_{2} \mathrm{O}\left([\mathrm{M} \cdot]^{+}\right)$162.0793, found 162.0797. Elemental Analysis calculated for $\mathrm{C}_{9} \mathrm{H}_{10} \mathrm{~N}_{2} \mathrm{O}$ : C 66.65\%; H 6.21\%; N 17.27\%; found C 66.51\%; H 6.33\%; N 17.06\%.

Empty MS2 Capsid Diels-Alder Conjugate (8). A $100 \mu \mathrm{L}$ aliquot of $4(\sim 0.5 \mathrm{mg} / \mathrm{mL})$ was passed through a S-300 microspin gel filtration column (as outlined above) to ensure the removal 
of dithionite reductant. To the resulting solution was added $1.0 \mu \mathrm{L}$ of an aqueous solution of sodium periodate $(100 \mu \mathrm{M})$, followed immediatedly by $10 \mu \mathrm{L}$ of 6 in $\mathrm{MeCN}(16 \mathrm{mg} / \mathrm{mL})$. The resulting reaction solution was incubated at room temperature for $2 \mathrm{~h}$ and then passed through a S-300 microspin gel filtration column. TEM was used to verify that the protein aggregates obtained after SEC were intact capsids (Figure 3d).

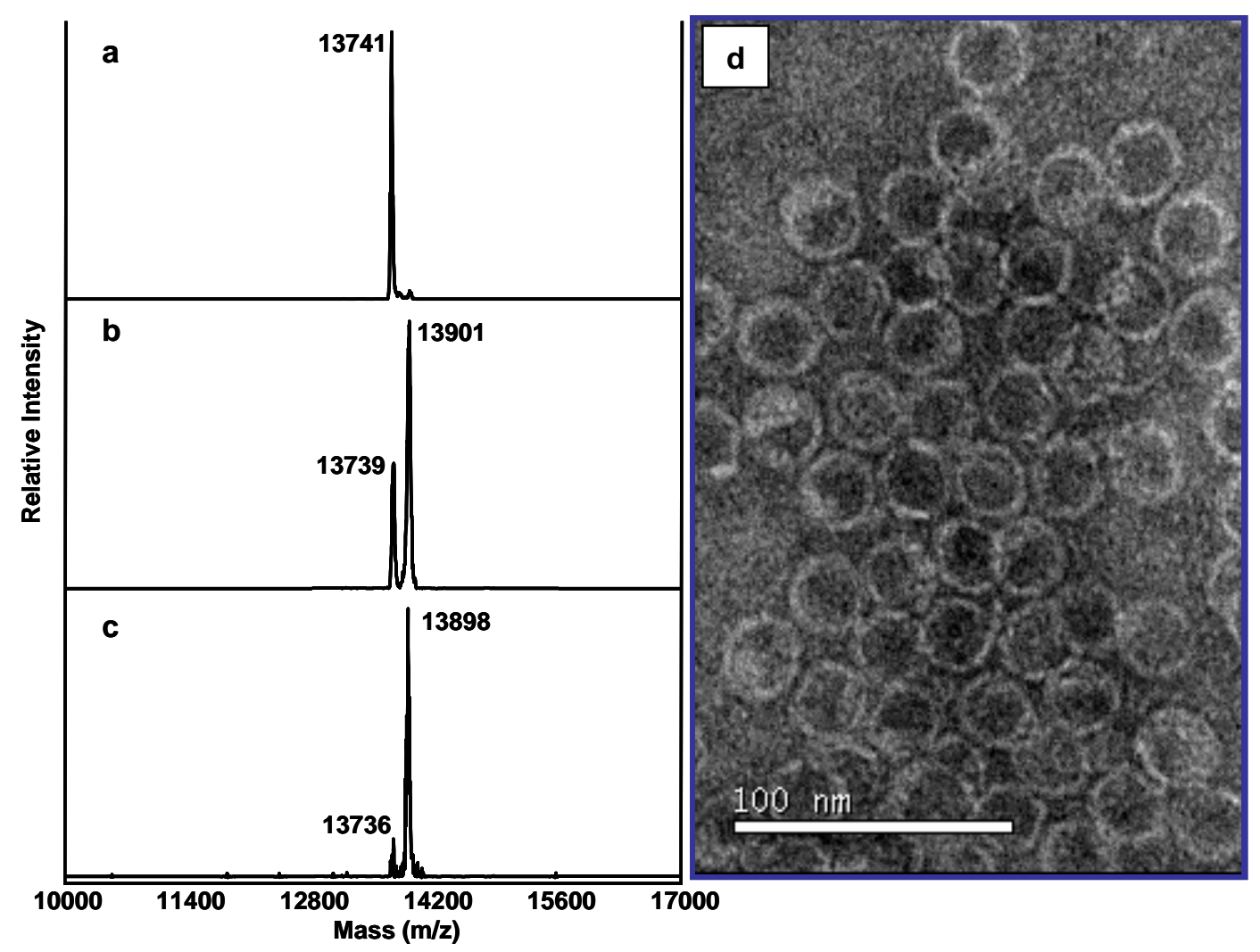

Figure 3. MALDI-TOF MS analysis of 8 over reaction time. a) MALDI MS of 4, expected $\mathrm{m} / \mathrm{z}=13745$. b) MALDI MS analysis of Diels-Alder reaction of $\mathbf{4}$ with $\mathbf{6}$ after $30 \mathrm{~min}$, expected $\mathrm{m} / \mathrm{z}=13903$. c) MS analysis of diazonium coupling reaction after $2 \mathrm{~h}$. d) TEM image of $\mathbf{8}$. No other protein aggregates were observed.

Diels-Alder Control Experiments. To verify that 8 arose specifically from reaction with $o$ iminoquinone moiety of 5, a solution of $\mathbf{1}$ was treated with $\mathbf{6}$ in both the presence and absence of sodium periodate under the same reaction conditions that afforded $\mathbf{8}$ from $o$-amino-tyrosine derivative 4. Analysis by MALDI-MS showed only unmodified protein after 4 days, indicating that no other residues on the protein participate in the reaction. Additionally, o-amino-tyrosine derivative $\mathbf{4}$ also proved unreactive in the presence of $\mathbf{6}$ without sodium periodate, as determined by MALDI-MS analysis. 
Preliminary Structure Elucidation. A solution of $4(0.5 \mathrm{mg} / \mathrm{mL})$ in $1: 1 \mathrm{H}_{2} \mathrm{O}: \mathrm{MeCN}$ was treated with $10 \%(\mathrm{v} / \mathrm{v})$ of benzyloxyamine $\left(\mathrm{BnONH}_{2}\right)$ in $\mathrm{MeCN}(20 \mathrm{mg} / \mathrm{mL})$ and $1 \%(\mathrm{v} / \mathrm{v})$ sodium periodate solution $(100 \mathrm{mM})$. The resulting solution was incubated at $95{ }^{\circ} \mathrm{C}$ for one hour. Analysis by MALDI-MS indicated that the addition of two $\mathrm{BnONH}_{2}$ molecules had occurred per monomer. Exposing adduct 8 to the same reaction conditions and analysis indicated that the addition of $\mathrm{BnONH}_{2}$ was not achieved. This preliminary evidence, with high resolution MALDI-TOF MS, suggests that 8 does not contain a ketone functional group.

General Procedure for Trypsin Digest Analysis of MS2 Conjugates. To an aqueous solution of MS2 conjugates ( $\mathrm{pH}$ 6.5-7.5) was added 10\% (v/v) MeCN followed by 5\% (v/v) sequencing grade modified trypsin solution $(40 \mu \mathrm{g} / \mathrm{mL})$ (Promega, USA). The resulting solution was briefly vortexed, and then incubated at $37{ }^{\circ} \mathrm{C}$ for $4 \mathrm{~h}$. The protein digest solution was desalted using a $\mu \mathrm{C} 18 \mathrm{ZipTip}^{\circledR}$ column (Millipore, USA) and the peptide fragments were analyzed by MALDI-TOF MS.

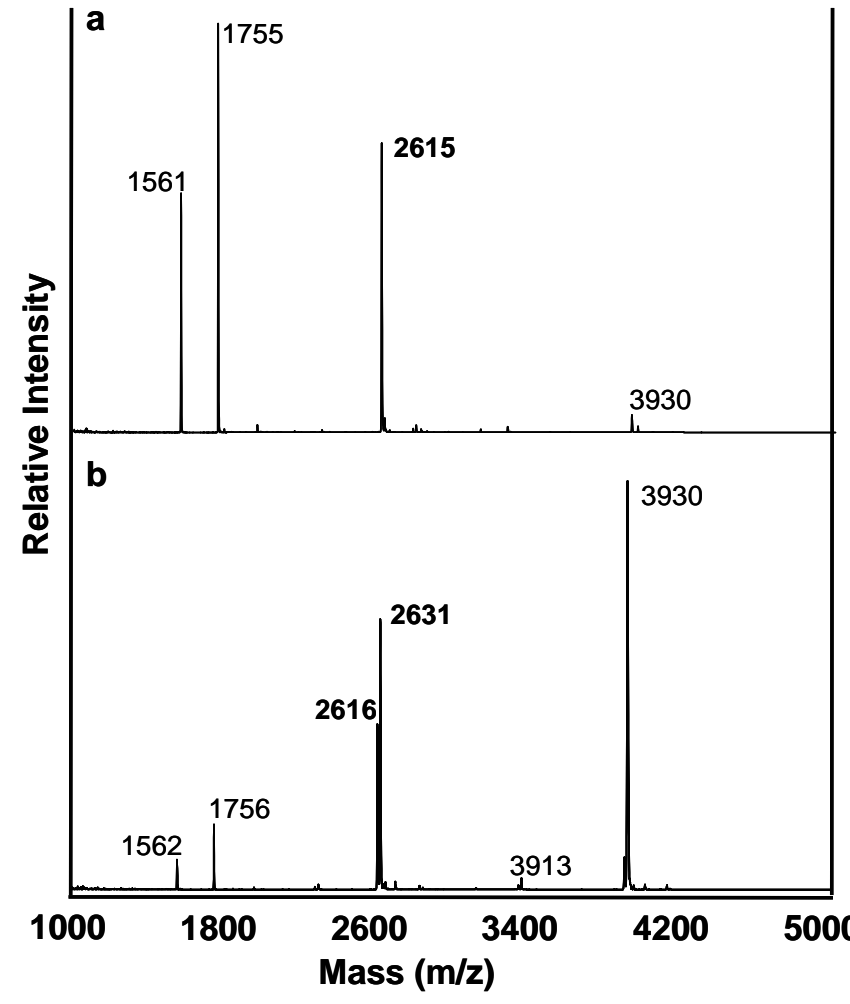

Figure 4. MALDI-TOF MS analysis of MS2 conjugate trypsin digests. The expected masses listed are for the Y85 containing fragment. a) MALDI MS analysis of unmodified empty MS2 1 digest, expected $\mathrm{m} / \mathrm{z}=2616$. b) MALDI MS analysis of o-amino-Y85 MS2 (4) digest, expected $\mathrm{m} / \mathrm{z}=2631$. Conversion was kept to less than $100 \%$ so that both the unmodified and modified fragments could be observed. c) MALDI MS analysis of Diels-Alder product 8, expected $\mathrm{m} / \mathrm{z}=2787$.

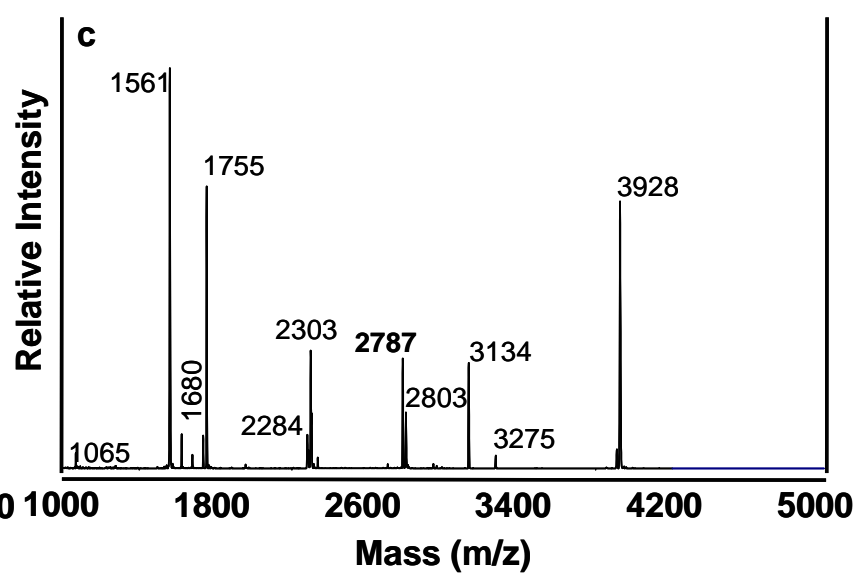




\section{References}

${ }^{1}$ Kussmann, M.; Nordhoff, E.; Pahbek-Nielson, H.; Haebel, S.; Rosel-Larsen, M.; Jakobsen, L.; Gobom, J.; Mirgorodskaya, E.; Kroll-Kristensen, A.; Palm, L.; Roepstorff, P. J Mass Spec 1997, 593.

${ }^{2}$ Laemmli, U. K. Nature 1970, 227, 680.

${ }^{3}$ (a) Strauss, J.; Sinsheimer, R. J Mol Biol 1963, 43. (b) Cargile, B.J.; McLuckey, S.A.; Stephenson, J.L., Jr. Analytical Chemistry 2001, 73, 1277. 